\title{
TANTANGAN DAN PELUANG GURU PENDIDIKAN AGAMA ISLAM DI ERA GLOBALISASI
}

\section{Nurhayati $^{1}$}

\begin{abstract}
Abstrak
Guru sebagai salah satu komponen dalam pendidikan, termasuk dalam pendidikan agama islam, merupakan salah satu komponen yang sangat menentukan bagi tujuan pendidikan agama islam yang relevan dan berorientasi pada peluang dan tantangan di era globalisasi. Karena itu dibutuhkan suatu pototipe atau model seorang guru agama yang sesuai dengan kondisi globalisasi tersebut.

Pendidikan agama islam disekolah merupakan usaha sadar, melalui bimbingan, pengajaran dan atau pelatihan guna mempersiapkan anak didik dalam rangka menyongsong masa depannya dengan menjadikan agama islam sebagai pegangan dan pedoman hidupnya.

Dalam proses belajar mengajar guru tidak hanya berperan sebagai penyampai ilmu pengetahuan, akan tetapi juga bertanggung jawab terhadap perkembangan kepribadian peserta didik. Guru harus menciptakan proses belajar sedemikian rupa, sehingga dapat merangsang peserta didik untk belajar efektif dan dinamis dalam memenuhi dan mencapai tujuan yang diharapkan. Dengan kemajuan yang dicapai dalam bidang ilmu pengetahuan dan teknologi akan semakin memicu perubahan yang terjadi diberbagai bidang kehidupan manusia yang sekaligus berdampak pada pergeseran nilai-nilai budaya dan agama dalam kehidupan umat manusia. Hal inilah yang menjadi tantangan-tantangan yang harus diantisipasi sedini mungkin agar tantangan-tantangan yang ada tidak menjadi ancaman menainkan menjadi suatu peluang yang menjanjikan.
\end{abstract}

\footnotetext{
${ }^{1}$ Penulis adalah tenaga pengajar pada STAIN Manado
} 
Kata kunci: Guru pendidikan agama islam, globalisasi

\section{A. Pendahuluan}

Slogan "guru sebagai pahlawan tanpa tanda jasa" atau "Guru sebagai pejuang peningkatan kecerdaan bangsa" merupakan slogan yang masih terus relevan sepanjang zaman. Terlebih-lebih dalam memasuki era globalisasi yang senantiasa menuntut optimalisasi fungsi dan peranan guru dalam meningkatkan sumber daya manusia yang di peerlukan dalam menghadapi tantangan pada era globalisasi tersebut di berbagai bidang kehidupan. Sebagaimana diketahui bahwa era globalisasi sangat menjanjikan peluangpeluang disamping juga membawa tantangan-tantangan yang sangat perlu di antisipasi sedini mungkin.

Pendidikan agama islam khususnya dilingkungan sekolah merupakan salah satu alternatif penting dan strategis dalam membina dan mengembangkan sumber daya manusia yang berkualitas dimana salah satu cirinya adalah beriman dan bertakwa terhadap Tuhan Yang Maha Esa, sebagaimana secara jelas diamanatkan dalam tujuan pendidikan nasional sesuai dengan (undang- undang nomor 2 tahun 1989:4) tentang sistem pendidikan nasional yang menyatakan bahwa : pendidikan nasional bertujuan mencerdaskan kehidupan bangsa dan mengembangkan manusia indonesia seutuhnya yaitu manusia yang beriman dan bertakwa terhadap Tuhan Yang Maha Esa dan berbudi pekerti luhur, memiliki pengetahuan dan keterampilan, kesehatan jasmani dan rohani, kepribadian yang mantap dan mandiri serta rasa tanggung jawab kemasyarakatan dan kebangsaan. ${ }^{2}$

Jika dicermati tujuan pendidikan nasional tersebut, maka terlihat bahwa yang utama dan pertama yang ingin dicapai oleh pelaksanaan dan proses

\footnotetext{
${ }^{2}$ Undang-undang RI No. 2 tahun 1989,Tentang Sistem Pendidikan Nasional, (Cet, 1; Jakarta: Gunung jati 1989), h.4
} 
pendidikan yang diselenggarakan di Indonesia adalah manusia yang memiliki kualitas iman dan ketakwaan yang tinggi dan dilengkapi dengan ilmu pengetahuan dan keterampilan, kesehatan jasmani dan rohani, dan rasa tanggung jawab, baik terhadap kehidupan masyarakat maupun bangsa. Oleh sebab itu untuk mencapai kualitas manusia yang beriman dan bertakwa ini, pendidikan agama islam mempunyai peranan dan fungsi yang sangat penting, terutama dalam menyongsong era globalisasi dan berbagai tantangan yang dihadapi. Hal ini sejalan dengan pandangan yang dikemukakan oleh Abduddin Nata yang menyatkan bahwa pendidikan agama memiliki peran yang amat besar dalam era globalisasi, yaitu selain menyiapkan manusiamanusia yang memilki iman dan takwa yang mantap, juga mampu menerjemahkan ajaran agama sesuai dengan perkembangan zaman. Dengan demikian, maka agama terasa fungsionalitasnya yang akrab dalam memecahkan masalah sosial. ${ }^{3}$

Dengan demikian, pendidikan agama pada era globalisasi tidak hanya dituntut fungsi dan perannya melainkan juga harus menyesuaikan dengan kondisi dan tantanga di era globalisasi.

Guru sebagai salah satu komponen dalam pendidikan termasuk guru agama islam merupakan salah satu yang sangat menentukan tujuan pendidikan agama islam yang relevan dan berorientasi pada peluang dan tantangan diera globalisasi. Karena itu dibutuhkan sesuatu prototipe atau model seorang guru agama yang sesuai dengan kondisi globalisasi tersebut. Dan hal inilah yang akan menjadi kajian dan telaah ini.

B. Pembahasan

1. Fungsi dan peranan guru pendidikan agama islam

\footnotetext{
3 Abuddin Nata, Peranan Pendidkan Agama Dalam Menghadapi Tantangan Abad ke-21, (Harian pelita, jumat 7 november 1997), h.4
} 
Guru merupakan salah satu bagian pendidikan yang sangat penting karena guru itulah yang bertaggung jawab dalam pembentukan pribadi anak didiknya. Terutama dalam pendidikan agama, guru mempunyai tanggung jawab yang lebih berat dibandingkan dengan pendidik pada umumnya, karena selain bertanggung jawab terhadap pembentukan akal pribadi anak yang sesuai dengan ajaran islam, ia juga bertanggung jawab terhadap Allah swt

Jabatan guru memiliki banyak tugas, baik yang terikat oleh dinas maupun diluar dinas, dalam bentuk pengabdian. Guru merupakan suatu profesi yang artinya suatu jabatan atau jenis pekerjaan yang memerlukan keahlian khusus sebagai guru. Jenis pekerjaan ini semestinya tidak dapat dilakukan oleh sembarang orang diluar bidang kependidikan meskipun kenyataannya masih dapat dilakukan orang non kependidikan. Dengan demikian guru memiliki fungsi dan peranan tersendiri dan penting dalam proses pendidikan dan pengajaran.

\section{a. Fungsi guru dalam pendidikan islam}

Hampir setiap diskusi selalu saja timbul pertanyaan kenapa terjadi begitu senjang dan terpisah antara satu sisi ajaran agama yang diyakini benar,hebat dan tinggi, dan disisi lain realitas perilaku para pemeluknya yang sama sekali berbeda dengan ajaran agamanya. Dalam ajaran islam ada sebuah pernyataan yang biasanya diyakini oleh kaum muslimin sebagai hadis Nabi yaitu penegasan bahwa "Islam itu sangat tinggi dan karenanya tidak ada yang lebih tinggi darinya “. Pernyataan ini yang sering di dengung-dengungkan untuk menegaskan bahwa islam itu hebat dan tinggi sehingga bila terjadi penyelewengan dan kezaliman yang 
dipersalahkan adalah para penganutnya, karena dianggap tidak memahami sekaligus tidak mempraktekkan ajaran agamanya secara benar. ${ }^{4}$

Sekilas memang argumen tersebut dapat diterima. Tapi bila dikritisi maka akan timbul pernyataan: jika ajaran islam itu memang benar, hebat, dan tinggi, tapi ternyata tidak mampu mempengaruhi para pemeluknya, lalu dimana pembuktian kebenaran kehebatan dan ketinggian ajarannya itu? Dan apa gunanya ajaran islam yang benar, hebat dan tinggi itu tapi tidak mampu mempengaruhi prilaku pemeluknya?

Inilah kira-kira problem umat islam saat ini dan tampaknya problem tersebut diakibatkan oleh adanya orientasi pendidikan agama yang kurang tepat. Tiga hal yang bisa dikemukakan untuk membuktikan kekurangtepatan orientasi pendidikan yang dimaksud:

Pertama, Pendidikan agama saat ini lebih berorientasi pada belajar tentang agama, karena itu tidak aneh kalau sering kita saksikan seseorang yang mengetahui nelai-nilai ajaran agama, tetapi perilakunya tidak relevan dengan nilai-nilai ajaran agama yang diketahuinya.

Kedua, Tidak tertibnya penusunan dan pemilihan materi-materi pendidikan agama sehingga sering ditemukan hal-hal yang prinsipil yang seharusnya dipelajari lebih awal, malah terlewatkan. Kekacawan materi pendidikan agama ini terlebih jelas lagi terlihat pada pemilihan disiplin ilmu fiqh yang dianggapnya sebagai agama itu sendiri. Disebabkan oleh orientasi pendidikan agama semacam itu, kita sering menyaksikan penilaian masyarakat menurut mereka, bahwa beragama yang benar adalah bermazhab fiqh yang benar dan yang diakui oleh mayoritas. Sedikit saja

4 Komaruddin Hidayat, Memetakan Kembali Struktur Keilmuan Islam Kata Pengantar dalam Fuaduddin dan Cik Hasan Bisri, Dinamika Pemikiran Islam di Perguruan Tinggi: Wacana tentang Pendidikan Agama Islam, (Jakarta: Logos 2002),h.xi 
berbeda dengan azhab yang dianut mayoritas, maka diklaim sebagai sesat dan menyimpang.

Ketiga, kurangnya penjelasan yang luas dan mendalam serta kurangnya penguasaan semantic dan generic atas istilah-istilah kunci dan pokok dalam ajaran agama sehingga sering ditemukan penjelasan yang sudah sangat jauh dan berbeda dari makna, spirit, dan konteksnya. Pada gilirannya kondisi semacam ini menjadikan ajaran-ajaran agama yang dipegang dan dianggap benar oleh para pemeluknya adalah ajaran agama yang sudah men-sejarah ratusan tahun. Sehingga seringkali tidak diketahui darimana sumbernya, apakah dari Al-Qur'an, Sunnah, atau dari pengalaman panjang kaum muslimin yang setiap periode tertentu membentuk dan mengkristalkan kepentingannya sehingga lama kelamaan kepentingan yang kontekstual itu dianggap sebagai peraturan islam dan diklaim sebagai bagian integral dari ajaran islam. Akibat pendidikan agama semacam ini, kaum muslimin biasanya lebih merasa benar berpegang kepada produk-produk pemikiran konfensional yang tidak begitu jelas dari mana berasal dari pada berpegang langsung kepada AlQur'an dan Sunnah. ${ }^{5}$

Tampaknya orientasi pendidikan agama semacam itulah yang menyebabkan kenapa terjadi keterpisahan dan kesenjangan antara satu sisi

5 Ibid.,h,xii-xiv. Hal yang sama juga di kemukakan oleh Abuddin nata bahwa pendidikan pada umumnya, termasuk pendidikan islam saat ini cenderung berhasil membina kecerdasan intelektual, dan keterampilan, dan kurang berhasil menumbuhkan kecerdasan emosional. Hal ini terjadi karena beberapa sebab, di antaranya adalah pertama, pendidikan yang diselenggarakan saat ini cenderung hanya pengajaran, dan bukan pendidikan. Kedua pendidikan saat ini sudah berubah dari orientasi nilai dan idealisme yang berjangka panjang kepada yang bersifat materialisme, individualisme, dan memntingkan tujuan jangka pendek. Ketiga, metode pendidikan yang diterapkan tidak bertolak dari pandangan yang elihat manusia sebagai makhluk yang paling mulia dan memiliki potensi yang bukan hanya potensi intelektual tetapi juga potensi emosional. Keempat,pendidikan islam kurang mengarahkan siswanya untuk mampu merespon sebagai masalah aktual yang muncul di masyarakat, sehingga terjadi kesenjangan antara dunia pendidikan dengan dunia kehidupan di masyarakat. Abuddin Nata,op.cit., h.53-54 
ajaran agama dan di sisi lain realitas perilaku para pemeluknya. Karena itu orientasi pendidikan agama yang selama ini perlu ditinjau ulang secara kritis untuk menemukan orientasi pendidikan agama yang lebih tepat dan berdaya guna. ${ }^{6}$

Zarkowi Soejoeti dalam makalahnya tentang "Model-model Perguruan Tinggi Islam', sebagaimana yang dikutip oleh A. Malik Fadjar mengemukakan bahwa pendidikan islam paling tidak mempunyai tiga pengertian. Pertama,lembaga pendidikan islam itu pendirian dan penyelenggaraannya didorong oleh hasrat mengejahwantakan nilai-nilai islam yang tercermin dalam nama lembaga pendidikan itu dan kegiatankegiatan yang diselenggarakan. Dalam pengertian ini, islam dilihat sebagai sumber nilai yang harus diwujudkan dalam kehidupan lembaa pendidikan yang bersangkutan. Kedua, lembaga pendidikan yang memberikan perhatian dan menyelenggarakan kajian tentang islam yang tercermin dalam program kajian sebagai ilmu dan diperlakukan sebagai ilmu-ilmu lain yang menjadi program kajian lembaga pendidikan islam yang bersangkutan. Ketiga, mengandung dua pengertian diatas dalam arti lembaga tersebut memperlakukan islam sebagai sumber nilai bagi sikap

${ }^{6}$ Terdapat dua pendekatan yang menonjol dalam mempelajari islam, pertama, mempelajari islam untuk kepentingan mengetahui bagaimana cara beragama yang benar. Disini aspek relegiusitas dan spirilualitas menjadi sangat penting sehingga esensi ajaran agama bisa menginternalisasi ke dalam diri pribadi-pribadi dalam aktivitas kesehariannya. Kedua, mempelajari islam sebagai sebuah pengetahuan. Pendekatan kedua ini berkembang sangat pesat di barat. Para peneliti dan pemikir yang memandang bahwa islam hanya sebgai pengetahuan adalah memang sangat terpisah dengan ajaran yang dikuasainya. Dalam orientasi pendidikan, kedua pendekatan mempelajari islam ini tampaknya perlu terus mendapat perhatian yang serius. Sehingga tidak saja terjadi peningkatan pengamalan religiusitas di kalangan para penganut islam, melainkan juga terjadi peningkatan keilmuan islam yang luar biasa. Dua pendekatan ini karenanya mesti menjadi orientasi pendidikan agama. Ibid., h.xiv$\mathrm{XV}$ 
dan tingkah laku yang harus tercermin dalam penyelenggaraannya maupun sebagai bidang kajian yang tercermin dalam program kajiannya. ${ }^{7}$

Konsep pendidikan islam sebagaimana dikemukakan oleh Zarkowi Soejoeti tersebut, walaupun belum cukup memadai secara falsafi untuk disebut sebagai pendidikan islam, tetapi dapat dijadikan sebagai pengantar dalam memahami pendidikan islam secara mendasar. ${ }^{8}$

Pendidikan dapat diartikan sebagai bimbingan atau pembinaan terhadap peserta didik. Pendidikan dapat diartikan secara sempit dan dapat pula diartikan secara luas. Secara sempit dapat diartikan sebagai bimbingan yang diberikan kepada anak-anak sampai ia dewasa. ${ }^{9}$ Pendidikan juga dapat diartikan secara luas yaitu segala sesuatu yang menyangkut proses perkembangan manusia, yaitu upaya menanamkan dan mengembangkan nilai-nilai bagi peserta didik, sehingga nilai-nilai yang terkandung dalam pendidikan itu menjadi bagian dari kepribadian peserta didik, yang pada gilirannya ia menjadi orang pandai, baik, mampu hidup dan berguna bagi masyarakat. ${ }^{10}$

Definisi diatas mengandung pengertian yang lebih luas, yakni menyangkut perkembangan dan pengembangan manusia. Namuun demikian pengertian ini masih terbatas dalam persoalan-persoalan duniawi yang belum memasukan aspek spritual religius sebagai bagian terpenting yang mendasari perkembangan dan pengembangan manusia dalam proses pendidikan.

\footnotetext{
${ }^{7}$ A. Malik Fadjar. Reorientasi pendidikan Islam, (Jakarta Fajar Dunia),1999),h.31

${ }^{8}$ Ibid

9 Ahmad D. Marimba, Pengantar Filsafat Pendidikan Islam, (Bandung: PT.al-

${ }^{10}$ M. Natsir Ali, Dasar-dasar Ilmu Mendiidik,(Jakarta: Mutiara,1997),h.23
} Ma'arif, 1981),h.3 
Syed Naquib al attas dalam hal ini menyatakan bahwa pendidikan berasal dari kata ta'diib. Memang terdapat kata lain selain ta'diib yaitu tarbiyah, akan tetapi tarbiyah lebih menekankan kepada mengasuh, menanggung, memberi makan, memelihara, menjadikan bertambah dalam pertumbuhan. ${ }^{11}$ Selanjutnya, Nuqaib menyatakan bahwa penekanan yang mencakup pada "adab" yang mencakup amal dalam pendidikan dan proses pendidikan adalah untuk menjamin bahwasanya ilmu dipergunakan secara baik dalam masyarakat. Karena alasan inilah orang-orang bijak terdahulu mengkombinasikan ilmu dengan amal dan adab, dan menganggap kombinasi harmonis ketiganya sebagai pendidikan. ${ }^{12}$

Pendidikan memang bukan sekedar transfer pengetahuan, pembinaan mental jasmani dan intelek semata, tetapi bagaimana pengetahuan dan pengalaman yang telah didapatkan dipraktekkan dalam prilaku sehari-hari. KI Hajar Dewantara dalam hal ini menyatakan bahwa pendidikan adalah usaha yang dilakukan dengan penuh keinsyafan yang ditujukan untuk keselamatan dan kebahagiaan manusia. Pendidikan tidak hanya bersifat pelaku pembanunan tetapi sering merupakan perjuangan pula. Pendidikan berarti memelihara hidup tumbh kearah kemajuan, tidak boleh melanjutkan keadaan kemarin. Pendidikan adalah usaha kebudayaan, berasas peradaban, yakni memajukan hidup agar mempertinggi derajat kemanusiaan. $^{13}$

${ }^{11}$ Sued Muhammad Naquib al attas, Konsep Pendidikan Dalam Islam,(Bandung: Mizan,1984),h.60

${ }^{12}$ Ibid.,h,59

${ }^{13}$ Ki Hajar Dewantara,Bagian Pertama Pendidikan, (Yogyakarta: Majlis Luhur Persatuan Taman Siswa, 1962),h.19 
Rumusan pendidikan diatas, tampak memberikan kesan dinamis, modern dan progresif. Pendidikan tidak boleh hanya memberikan bekal untuk membangun, tetapi seberapa jauh didikan yang diberikan itu dapat berguna untuk menunjang kemajuan suatu bangsa. Semangat progresif yang terkandung dalam pendidikan sebagaimana definisi diatas, tampak mengingatkan kita pada pesan Khalifah umar yang menyatakan bahwa anak-anak mudah masa sekarang adalah generasi dimasa yang akan datang. Dunia dan kehidupan yang akan dihadapi berbeda dengan dunia yang sekarang, untuk itu apa yang akan diberikan pada anak didik harus diperlihatkan kemungkinan relevansi dan kegunaannya dimasa yang akan datang. ${ }^{14}$

Menurut H,M. Arifin, dengan mengutip rumusan dari hasil seminar pendidikan islam se-Indonesia di Cipayung Bogor tanggal 17-11 mei 1960, menyatakkan bahwa pendidikan islam adalah sebagai bimbingan terhadap pertumbuhan rohani dan jasmani menurut ajaran islam dengan hikmah mengarahkan, mengajarkan, melatih, mengasuh dan mengawasi berlakunya semua ajaran islam. Islam membimbing, mengarahkan dan mengasuh serta mengajarkan atau melatih, mengandung pengertian usaha mempengaruhi jiwa anak didik melalui proses setingkat demi setingkat menuju tujuan yang ditetapkan, yaitu menanamkan takwa dan akhlak serta menegakkan kebenaran sehingga terbentuklah manusia yag berpribadi dan berbudi luhur sesuai sengan ajaran islam. ${ }^{15}$

Setidak-tidaknya ada tiga poin yang dapat disimpulkan dari definisi pendidikan diatas, yaitu: 1) Pendidikan islam menyangkut aspek jasmani dan rohani. Keduanya merupakan satu kkesatuan yang tidak dapat

${ }^{14}$ Abuddin Nata, Filsafat Pendidikan Islam, (Jakarta: Logos Wacana Ilmu,2001),h. $9-10$

${ }^{15}$ H.M Muzayyin Arifin, Filsafat Pendidikan Islam, ( Jakarta: PT Bina Aksara, 1987),h.13 
dipisahkan. Oleh karena itu, pembinaan terhadap keduanya harus serasi, selaras, dan seimbang 2) pendidikan islam mendasarka konsepnya pada nilai-nilai religius. Ini berarti bahwa pendidikan islam tidak mengabaikan faktor teologis sebagai sumber dari ilmu itu sendiri, sebagaimana Q.S AlBaqarah:31: “ Dan dia mengajarkan kepada adam nama-nama (bendabenda) seluruhnya, kemudian mengemukakannya kepada para malaikat, lalu berfirman: Sebutkanlah kepadaKu nama-nama benda itu jika kamu memang orang-orang yang benar.

Ayat ini menunjukan adanya epistemologi dalam islam, yaitu bahwa ilmu pengetahuan bersumber dari Allah. Dialah pendidik yang pertama dan utama. Bedanya dengan orang tua sebagai pendidik yang pertama dan utama adalaha bahwa orang tua merupakan pendidik pertama bagi anakanaknya dalam keluarga. Allah adalah pendidik utama dan pertma bagi seluruh makhluk manusia, bahkan seluruh alam. Tidak ada satu pendidikan yang terjadi dalam keluarga, bahkan dalam alam jagat raya ini, tanpa Allah sebagai pendidik pertama dan utama yang mengajarkan ilmunya kepada manusia dalam hal ini Adam sebagai manusia pertama. 3) adanya unsur takwa sebagai tujuan yang harus dicapai. Sebagaimana yag kita ketahui bahwa takwa merupakan benteng yang dapat berfungsi sebagai daya tangkal terhadap pengaruh-pengaruhnegatif yang datamg dari luar.

Selanjutnya Mappanganro dalam bukunya Implementasi Pendidikan Islam di Sekolah, menyatakan bahwa pendidikan agama islam pengertiannya lebih luas apabila dibandingkan dengan pelajaran atau pengajaran agama islam. Pendidikan islam tidak hanya bersifat mengajar, dalam arti menyampaikan ilmu pengetahuan tentang agama islam kepada 
anak didik atau peserta didik, melainkan melakukan pembinaan mental spiritual yang sesuai dengan ajaran agama islam. ${ }^{16}$

Sedangkan pengertian agama islam yang dirumuskan oleh Ditbinpaisun ialah usaha sadar yang dilakukan orang dewasa terhadap anak didik menuju tercapainya manusia beragama ( manusia yang bertakwa kepada Allah Tuhan Yang Maha Esa). ${ }^{17}$

Demikian pula pengartian pendidikan agama yang dikemukakan oleh Zakiah Daradjat dan kawan-kawan mengemukakan:

a. Pendidikan agama islam usaha berupa bimbingan dan asuhan terhadap anak didik agar kelak setelah selesai dapat memahami dan mengamalkan ajaran agama islam serta menjadikannya sebagai pandangan hidup atau way of life.

b. Pendidikan agama islam ialah pendidikan yang dilakukan berdasarkan ajaran islam

c. Pendidikan agama islam adalah pendidikan dengan melalui ajaranajaran agama islam, yaitu berupa bimbingan dan asuhan terhadap anak didik agar nantinya setelah selesai dari pendidikan ia dapat memahami, menghayati, dan mengamalkan ajaran-ajaran agama islam itu sebagai suatu pandangan hidupnya demi keselamatan dan kesejahteraan hidupdidunia maupun diakhirat nanti. ${ }^{18}$

Berbagai pengertian pendidikan agama islam yang dikemukakan itu pada prinsipnya sejalan dengan Undang-undang Sistem Pendidikan Nasional. Dalam Undang-undang Sistem Pendidikan Nasional pada pasal

${ }^{17}$ Ditbimpaisum, Pedoman Pembinaan Guru Agama Islam Pada Sekolah Umum, Jakarta: Dirjen Binbaga Islam Direktorat Pembinaan Pendidikan Agama Islam, 1990/1991. h, 5.

${ }^{18}$ Zakiyah Daradjat, et.all., Ilmu Pendidikan Islam, Jakarta: Bumi Aksara,1992,h. 86 
39 ayat 2 yang dalam penjelasannya dinyatakan bahwa: pendidikan agama merupakan usaha untuk memperkuat iman dan ketakwaan terhadap Tuhan Yang Maha Esasesuai dengan agama yang dianut oleh peserta didik yang bersangkutan dengan memperhatikan tuntutan untuk menghormati agama lain dalam hubungan kerukunan antar umat beragama dalam masyarakat untuk mewujudkan persatuan nasional. ${ }^{19}$

Dengan demikian, secara singkat dapat dikemukakan bahwa pendidikan agama islam disekolah merupakan usaha sadar, melalui bimbingan, pengajaran dan atau pelatihan guna mempersiapkan anak didik dalam rangka menyongsong masa depannya dengan menjadikan ajaran islam sebagai pegangan dan pedoman hidupnya. Oleh sebab itu, pendidikan agama islam memiliki beberapa fungsi sebagai berikut:

\section{1) Fungsi pewarisan atau pemindahan nilai-nilai}

Fungsi pewarisan atau pemindahan nilai-nilai yang tidak lain adalah nilai-nilai yang terkandung dalam ajaran islam yang bersumber dari AlQur'an dan Sunnah, baik dari aspek aqidah, syariah maupun dari aspek akhlak. Hal ini sejalan dengan pandangan yang dikemukakan oleh Hasan Langgulung bahwa dahulu kala fungsi utama pendidikan adalah pemindahan nilai-nilai dari generasi tua ke generasi mudah agar identitas suatu masyarakat terpelihara adanya. Nilai-nilai perlu tetap dipelihara demi kebutuhan dan kelangsunan hidup masyarakat. Sebab masyarakat yang tidak punya nilai-nilai akan hancur sendiri. ${ }^{20}$

${ }^{19}$ Undang- undang Nomor 2 Tahun 1998 Tentang Sistem Pendidikan Nasional, Himpunan Peraturan-Peraturan Bidang Pendidikan dan Kebudayaan Departemen P dan K. RI.,1992/1993,H.46

${ }^{20}$ Hasan Langgulung, Asas-asas Pendidikan Islam, Cet.2, Jakarta: Pustaka AlHusna,1988,h. 359 
Fungsi pewarisan atau pemindahan nilai-nilai ini merupakan fungsi pendidikan agama islam tetap menjadi fungsi penting dan utama, bukan saja dahulukala melainkan sampai saat inipun, bahkan pada masa-masa yang akan datang tetap harus dipertahankan. Untuk itulah pendidikan agama islam sangat mengutamakan pewarisan nilai-nilai yang terkandung di dalam materi yang disajikan sebagai bekal dan pembinaan kepribadian anak didik. Sebagaimana yang diutarakan oleh Hasan Langgulung tersebut bahwa suatu masyarakat tidak memiliki pegangan dan pedoman hidup, yakni nilai-nilai yang mempunyai kebenaran dan diyakini setiap individu akan dapat mengalammi kehancuran.

2) Ilmu dan keterampilan dari generasi ke generasi

Ilmu adalah prinsip-prinsip yang digunakan untuk memahami alam jagat dan pencipta-Nya serta memahami manusia itu sendiri. Prinsipprinsip inilah yang dipindahkan dari generasi ke generasi, tidak perlu produk lainnya.

Berkaitan dengan ilmu dan keterampilan, keterampilan merupakan kemampuan membuat sesuatu walaupun tidak memahami prinsip sesuatu berlaku demikian. Sebagai contoh dalam hal mengemudikan mobil merupakan keterampilan, sebab mengemudikan mobil tidak selalu memiliki arti bahwa tidak ada pengemudi yang tau prinsip itu. Keterampilan-keterampilan ini juga merupakan suatu upaya yang dilakukan melalui proses pendidikan dalam rangka melestarikan kebudayaan yang tumbuh di masyarakat, dengan maksud agar hal-hal yang sifatnya keterampilan dapat juga dipertahankan sebagai suatu ciri dari suatu masyarakat. Dan inilah salah satu fungsi pendidikan tersebut.

Kaitannya dengan fungsi pendidikan agama sesungguhnya tidak jauh berbeda dengan fungsi pendidikan lainnya sebagaimana yang 
dikemukakan tersebut dimana pendidikan agama juga sangat mengutamakan pewarisan nilai-nilai yang terkandung didalam materi yang disajikan sebagai bekal dan pembinaan kepribadian anak didik, guna menyongsong masa depan dengan menjadikan nilai-nilai ajaran agama islam sebagai pedoman hidup atau "way of life".

3) Pembetukan peranan-peranan ditengah-tengah masyarakat

Fungsi ini mengisyaratkan bahwa pendidikan agama islam tidak hanya mementingkan aspek keakhiratan saja melainkan juga ia senantiasa memperhatikan aspek-aspek keduniaan yang berhubungan erat dengan pendidikan dan pembinaan bagi setiap individu untuk mempersiapkan dirinya untuk memegang peran-peran dalam berbagai aspek kehidupan guna memepertahankan hidup dan kehidupannya.

Dengan demikian fungsi guru pendidikan agama islam juga tidak terlepas dari fungsi dari pendidikan agama islam tersebut, yakni berupaya mendorong anak didiknya guna mewujudkan fungsi-fungsi individu didalam kehidupan masyarakat melalui proses pendidikan dan pengajaran yang sesuai dengan nilai-nilai ajaran islam.

b. Peranan guru dalam pendidikan agama islam

Peranan guru mengutip pendapat dari Muh. Uzer Usman adalah serangkaian tingkah laku yang saling berkaitan yang dilakukan dalam situasi tertentu serta berhubungan dengan kemajuan perubahanperubahann tingkah laku dan perkembangan siswa yang menjadi tujuannya. $^{21}$

21 Moh. Uzar Usman, Menjadi Guru Profesional, Cet,I, (Bandung: Rosdakarya,1994)h, 1 
Lebih jauh H. Abu Ahmadi dengan membatasi peranan guru dalam proses belajar mengajar adalah:

1. Mendidik peserta didik dengan titik berat memberikan arah dan motivasi pencapaian tujuan dengan baik jangkah pendek maupun jangkah panjang

2. Memberi fasilitas pencapaian tujuan melalui pengalaman belajar yanng memadai

3. Membantu perkembangan aspek-aspek pribadi, sikap, nilai-nilai dan penyesuaian diri. ${ }^{22}$

Dalam proses belajar mengajar, guru tidak hanya berperan sebagai penyampai ilmu pengetahuan, akan tetapi juga bertanggung jawab terhadap perkembangan kepribadian peserta didik. Guru harus menciptakan proses belajar sedemikian rupa, sehingga dapat merangsang peserta didik untuk belajar efektif dan dinamis dalam memenuhi dan mencapai tujuan yang diharapkan

Peran guru sangat besar sebagai pelaksana langsung kurikulum khususnya pada pendidikan formal, tugas guru besar atau kecil adalah mendidik bukan hanya mengajarkan suatu bidang studi. Karena itu guru harus memiliki atau dibekali ketakwaan kepada Allah, kepribadian yang kuat ilmu kependidikan dan keguruan. Dalam pandangan A .M. Saefuddin sebagaimana dinyatakan bahwa guru adalah contoh kebaikan atau teladan kebaikan yang hidup bagi anak didik dan lingkungannya. Peranan dan tanggung jawab guru akan meningkat lebih bila kualitas guru di tingkatkan, keprofesiannya dikembangkan terus menerus dan berorientasi futuristik, tanpa melupakan peningkatan kesejahteraannya,

${ }^{22}$ Abu Ahmadi et all., Psikologi Belajar, (Jakarta: Rineka Cipta, 1991) h.99 
misalkan pangkat, gaji, kesehatan, perubahan dan lain-lain yang perlu mendapat perhatian. ${ }^{23}$

Dengan demikian keberadaan guru bukan hanya sebagai pengajar yang berusaha mentransformasikan (memindahkan) ilmu pengetahuan kepada anak didiknya melainkan juga berperan dalam upaya membina dan membimbing anak didiknya kearah kemajuan suatu masyarakat bahkan kemajuan suatu bangsa, peranan guru ini tampak sebagaimana yang dipaparkan oleh Hasan Langgulung yang menyatakan bahwa sejarah senantiasa mencritakan bagaimana guru itu memegang peranan-peranan penting dalam menjalankan dan mengendalikan pimpinan negara dan kerajaan pada zaman dahulu kala. Dalam sejarah Mesir kuno guru-guru itu adalah filosof-filosof yang menjadi penasehat raja. Kata-kata guru itu menjadi pedoman dalam memimpin negara. Dalam zaman kegemilangan falsafah Yunani, Socrates, Plato dan Aristoteles adalah guru yang mempengaruhi perjalanan sejarah Yunani.

Dalam sejarah Islam, guru dan ulama itu selalu bergandengan atau ulama itu juga adalah guru, Nabi sebagai penerima wahyu mengajarkan wahyu itu kepada pengikut-pengikutnya. ${ }^{24}$ Senada dengan hal iitu, Zakiah Darajat telah pula menggambarkan tentang peranan guru itu khusunya di negara-negara Timur sejak dahulu bahkan sampai saat ini. Ia menyatakan bahwa di negara-negara Timur sejak dahulu kala guru itu dihormati oleh masyarakat. Orang India dahulu, menganggap guru itu sebagai orang suci dan sakti. De jepang, guru disebut sensei, artinya yang lebih dulu lahir “yang lebih tua”. Di Inggris guru itu di katakan "teacher" dan di Jerman “der lehrer", keduanya berarti pengajar, akan tetapi guru sebenarnya

${ }^{23}$ A. M. Saefuddin, Desekularisasi Pemikiran; Landasan Islamisasi, Cet. (Bandung: Mizan, 1997) h. 130

${ }^{24}$ Hasan Langgulung, Manusia dan Pendidikan (Suatu Analisa Psikologis dan Pendidikan) Cet I, (Jakarta: Pustaka Al- Husna,1989),h. 228 
bukan saja mengandung arti "pengajar", melainkan juga "pendidik" baik didalam maupun diluar sekolah. Ia harus menjadi penyulu masyarakat. ${ }^{25}$

Demikianlah gambaran tentang pentingnya peranan seorang guru didalam fungsinya sebagai pembina, pembimbing dan pengajar dari suatu masyarakat dari zaman ke zaman bahkan fungsi dan peranannya tersebut akan terasa lebih penting dalam memasuki era baru, yaitu era globalisasi dengan segala peluang dan tantangan.

\section{Tugas dan tanggung jawab guru pendidikan agama islam}

Tugas guru sebagai profesi termasuk dalam hal ini guru pendidikan agama islamsebagai suatu profesi, mencakup mendidik, mengajar dan melatih. Mendidik berarti meneruskan dan mengembangkan nilai-nilai hidup. Mengajar dapat diartikan sebagai upaya meneruskan dan mengembangkan ilmu pengetahuan dan teknologi. Sedangkan melatih bermakna mengembangkan berbagai keterampilan pada siswa. Disamping itu guru juga mempunyai tugas-tugas dibidang kemanusiaan. Tugas guru di bidang kemanusiaan ini menekankan bahwa guru disekolah harus dapat menjadikan dirinya sebagai orang tua kedua. Dengan tugas guru di bidang kemanusiaan ini, guru di tuntut untuk mampu menarik simpati sehingga ia menjadi idola para siswanya. Pelajaran apapun yang diberikannya, hendaknya dapat menjadikan pendorong bagi siswanya dalam belajar.

Tugas dan tanggung jawab guru tidaklah terbatas didalam masyarakat, bahkan guru termasuk dalam hal ini pada hakekatnya merupakan komponen strategis yang memiliki peranan dan tanggung jawab penting dalam menentukan gerak maju kehidupan bangsa.

\footnotetext{
${ }^{25}$ Zakiyah Daradjat, Ilmu Pendidikan Islam, Cet II, (Jakarta: Bumi Aksara,1992) h.
} $39-40$ 
Tugas guru pendidikan agama merupakan tugas yang mulia sebab ia bukan saja mengajarkan pengetahuan agama islam tetapi mendidik anak untuk menjadikannya orang mukmin dan muslim, yang dapat menjadikan agama islam sebagai jalan hidupnya.sejalan dengan hal ini di dalam uraiannya Muhammad Ahmad menegaskan bahwa guru agama merupakan tumpuan harapan dari orang tua anak untuk menjadikan anak-anak mereka anak yang baik (anak shaleh) yang tau menjalankan kewajiban agamanya dan memiliki budi pekerti yang luhur (akhlakul karimah). Tetapi lebih dari keluhuran tugas guru agama dikarenakan ia merupakan pelanjut tugas risalah. ${ }^{26}$

Tugas dan tanggung jawab yang di emban oleh guru sebagaimana di kemukakan diatas, secara jelas pula di tegaskan oleh Allah swt, dalam firman-Nya surat Ali-Imran (3) ayat 164:

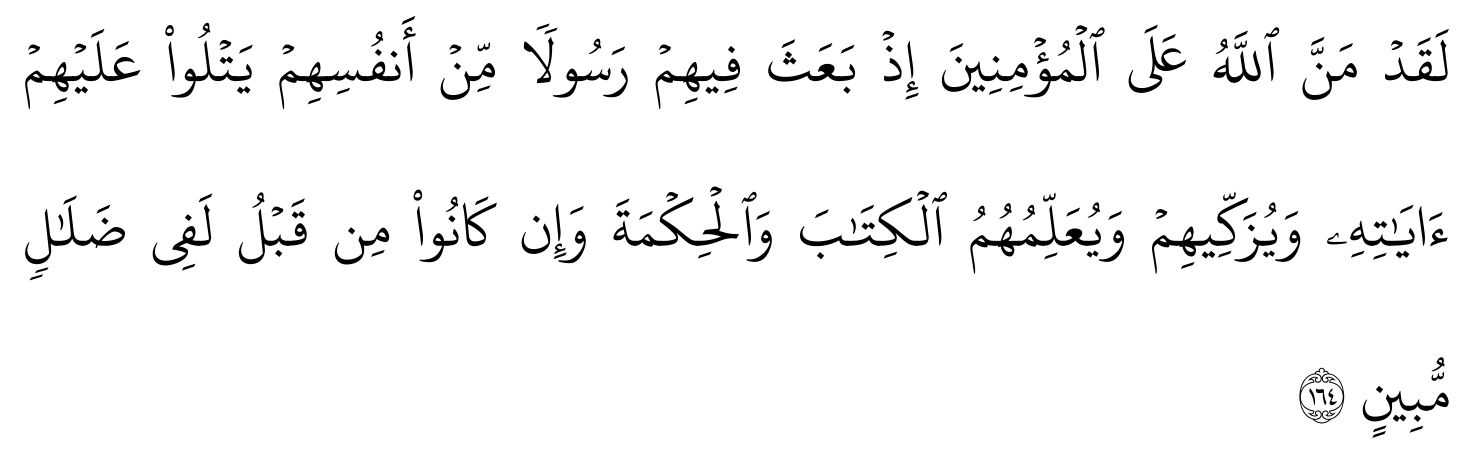

Terjemahnya:

sungguh Allah telah memberi karunia kepada orang-orang yang beriman ketika Allah mengutus diantara mereka seorang Rasul dari golongan mereka sendiri, yang membacakan kepada mereka ayat-ayat

26 Muhammad Ahmad, Tanggung Jawab Pendidikan Agama Islam (Diktat Ilmu Pendidikan Islam), Ujung Pandang: IAIN Alauddin,1991) h,38 
Allah, membersihkan (jiwa) mereka, dan mengajarkan kepada mereka Al kitab dan Al hikmah. dan Sesungguhnya sebelum (kedatangan Nabi) itu, mereka adalah benar-benar dalam kesesatan yang nyata. ${ }^{27}$

Abdurrahman An-Nahlawi dalam bukunya "Ushul al Tarbiyah wa Aslibuha", mengatakan bahwa ayat ini menjelaskan kewajiban pokok seorang pendidik (guru agama) adalah:

a. Mensucikan atau menumbuhkan dan membersihkan untuk sampai kepada Tuhannya dan menjaukan dari kejahatan serta menjaga fitrah kesuciannya.

b. Mengajar atau memindahkan sejumlah pengetahua dan aqidah kedalam akal dan hati orang-orang mukmin untuk mereka laksanakan didalam perilaku dan kehidupan mereka. ${ }^{28}$

Tugas-tugas yang di emban oleh guru agama tersebut juga akan menjadi tanggung jawab yang harus tetap dilaksanakan oleh guru pendidikan agama itu yang sekaligus diberikan amanah oleh Allah dan kepercayaan dari orang tua dan masyarakat bahkan bangsa dan negara. Mengenai tugas dan tanggung jawab guru pendidikan agama bahkan juga guru-guru lainnya di jelaskan oleh Zakiah Darajat bahwa guru adalah pendidik profesional, karenanya secara implisit ia telah merelakan dirinya menerima dan memikul sebagian tanggung jawab pendidikan yang terpikul di pundak para orang tua. Mereka ini, tatkala menyerahkan anaknya ke sekolah, sekaligus berarti pelimpahan sebagian tanggung jawab pendidikan anaknya kepada guru. Hal itupun menjukan pula bahwa

27 Departemen Agama RI., Al-Qur'an dan Terjemahnya, (Jakarta: Yayasan Penyelenggara Penterjemah dan Penafsir Al-Qur'an, 1991)h. 324

28 Abdurrahman Al-Nahlawi, Usul Al-Tarbiyah al-Islamiah wa Aslibuha, (Kairo: Darul Fikri,1955) h,155. 
orang tua tidak mungkin menyerahkan anaknya kepada sembarang guru/ sekolah karena tidak sembarang orang dapat menjabat guru. ${ }^{29}$

Dengan demikian tugas dan tanggung jawab guru khususnya guru pendidikan agama islam merupakan suatu tugas dan tanggung jawab yang teramat mulia yang dijelaskan oleh Zuhairini yang meliputi:

1. Mengajarkan ilmu pengetahuan agama islam

2. Menanamkan keimanan dalam jiwa anak

3. Mendidik anak agar taat menjalankan agama

4. Mendidik anak agar berbudi pekerti yang mulia ${ }^{30}$

Tugas dan tanggung jawab guru yang dipikul oleh guru pendidikan agama islam sebagaimana yang dikemukakan tersebut bukan saja pertanggung jawabannya kepada anak didik, orang tua anak didik, masyarakat, bangsa dan negara melainkan juga sebagai amanah yang diberikan oleh Allah swt., untuk mendidik, membimbing anak didik agar dapat menjadi manusia yang mukmin dan muslim.

Agar supaya para guru pendidikan agama islam dapat melaksanakan tugas dan tanggung jawabnya tersebut dengan sebaik-baiknya, dibutuhkan syarat-syarat tertentu, disamping syarat-syarat yang harus dimiliki oleh guru-guru pada umumnya.

\section{Tantangan guru pendidikan agama pada era globalisasi}

Globalisasi merupakan kecenderungan terbukanya sekat-sekat pembatasan dari berbagai faktor kehidupan seperti; batas wilayah, sosial, geografis, budaya, ekonomi dan aspek-aspek lainnya yang dipicu dan dipacu oleh kemajuan media komunikasi. Hal ini sejalan dengan pandangan yang dikemukakan oleh Abduddin Nata menyatakan bahwa

${ }^{29}$ Zakiyah Darajat op. cit., h.39

${ }^{30}$ Zuhairini, Metodik Kusus Pendidikan Islam, Cet I, (Surabaya: Biro Ilmiah Fakultas Tarbiyah IAIN Sunan Ampel Malang, 1983), h.35 
abad ke 21 yang selanjutnya disebut era globalisasi adalah merupakan suatu keadaan dimana antara manusia dengan manusia lainnya yang berlatar belakang geografis, budaya, agama, nilai-nilai, bahasa lainnya akan dapat disatukan melalui teknologi komunikasi seperti radio, televisi, telepon, faksimili, dan lain sebagainya. Melalui peralatan tersebut, maka manusia akan mengetahui berbagai keadaan yang terjadi dibelahan dunia lain dalam waktu yang bersamaan. ${ }^{31}$

Sedangkan dalam makalah yang diterbitkan badan pembinaan pendidikan pelaksanaan pedoman penghayatan dan pengamalan pancasila memberikan definisi era globalisasi dengan menyatakan bahwa globalisasi secara praktis dapat di nyatakan sebagai suatu kondisi global dimana batas-batas negara akan semakin lemah efektifitasnya dalam menghambat berbagai macam arus dari luar dalam suatu negara, dan dalam mendorong berbagai macam arus dari dalam keluar suatu negara. ${ }^{32}$

Berdasarkan kedua pengertian globalisasi atau era globalisasi tersebut, memberikan pemahaman bahwa globalisasi memiliki inti pengertian terbukanya atau menyatunya bagian-bagian aspek kehidupan manusia yang mencakup seluruh sektor kehidupan yang di dorong oleh kemajuan teknologi informasi, dengan berbagai bentuk media penyampaiannya.

Senada dengan hal tersebut, A.M. Saefuddin dalam sebuah tuisannya mengatakan bahwa perubahan-perubahan global yang sedang dan akan terjadi dalam masa depan yang dekat yakni sebagai berikut: pertama,globalisasi informasi dan komunikasi, sebagai akibat dari kemajuan teknoloogi dan pembangunan sarana/prasarana informasi dan

${ }^{31}$ Abuddin Nata, Peranan Pendidikan Agama Dalam Menghadapi Tantangan Abad 21, Harian Pelita, 7 November 1997,h.4

${ }^{32}$ Badan Pembina Pendidikan PelaksanaPenghayatan dan Pengamalan Pancasila, Rumusan Diskusi Kelompok Aktualisasi Pertumbuhan pada Perguruan Tinggi, h. 5 
komunikasi dengan jangkauan yang makin global. Kedua, globalisasi ekonomi dan perdagangan bebas, globalisasi keuangan dan pemilikan kapital, globalisasi pasar dan perusahaan tradisional "corporation" ketiga, globalisasi gaya hidup dan pola komsumsi, globalisasi budaya, globalisasi persepsi dan kesadaran.keempat, globalisasi media massa cetak dan elektronik. Kelima, globalisasi politik dan wawasan. ${ }^{33}$

Dengan era globalisasi kecepatan dan percepatan makin tinggi, kapasitas atau kemampuan lebih besar untuk menyebarkan informasi yang makin banyak ragamnya. Demikian pula dengan pembangunan berbagai jaringan informasi seperti jaringan internet memiliki jangkauan global yang lebih penuh dan merata, sangat beragam dan Heterogen.

Dampak lain dari globalisasi adalah lahirnya gaya hidup dan pola komsumtif. Hal ini terjadi melalui proses pengalihan dan penyerapan gaya hidup baru yang dominan. Sebagaimana di gambarkan oleh Yusuf Amier Feisal yang menyatakan bahwa globalisasi berbagai bidang kehidupan, seperti ekonomi dan perdagangan, kebudayaan, informasi melalui media elektronika memunculkan gaya hidup dan gaya yang bersifat global pula. Diberbagai kota besar di Indonesia, kita dapat menyaksikan gaya hidup lapisan masyarakat yang mencerminkan gaya masyarakat negara maju (barat). Gaya hidup yang berakar pada budaya asing tersebut tentu tidak selamanya sesuai dengan sendi-sendi budaya nasional. Keterbukaan kita terhadap arus informasi global melalui media elektrinik seperti TV, berbagai program komputer, dan sebaginya selain

${ }^{33}$ A. M. Saefuddin, Pendidikan Pesantren dan Globalisasi Serial Khotbah Jumat. No 203 Mei 1998,h. 68-69 
menunjukan sisi positif yang memperkaya budaya kita juga tidak jarang berdampak negatif. ${ }^{34}$

Dalam era informasi ini, telah muncul globalisasi televisi. Kondisi ini ditandai dengan adanya siaran televisi global secara sengaja melintas tapal batas guna mencapai sasaran penonton di berbagai negara, tidak terkecuali penonton di indonesia. Sebagaimana di ketahui menjelang akhir tahun 1991, sebagian tanah air telah di terpa oleh siaran TV Satelite Televison Asian Region atau di singkat STAR I Hongkong dengan lima saluran selama 24 jam sehari melalui Asia Sat. I, gambaran hal ini Paul Legerd sebagaimana yang dikutip oleh Chotibul Umam menyatakan bahwa kemajuan informasi seperti itu mempunyai dampak yang besar sekaligus merupakan tantangan bagi umat manusia, dan khususnya umat islam, di samping tantangan- tantangan lainnya. ${ }^{35}$

Senada denga itu pula Muhammad Ali Yafie dalam sebuah tulisannya menguraikan bahwa: arus globalisasi yang disertai dengan kecenderungan liberalisasi perdagangan dunia dapat menyebabkan terjadinya pergeseranpergeseran dalam berbagai aspek nilai dan norma kehidupan yang pada gilirannya dapat mempengaruhi dan menimbulkan persoalan-persoalan akhlak dalam kehidupan kemasyarakatan dan kebangsaan kita. ${ }^{36}$

Dari pernyataan tersebut tersimpul bahwa disamping bernilai atau berdampak positif yang membawa harapan-harapan dimasa yang akan datang bila dimanfaatkan seoptimal mungkin, juga akan membawa dampak-dampak negatif yang dapat mengancam kehidupan manusia

${ }^{34}$ Jusuf Amier Feisal, Reorientasi Pendidikan Islam, Cet I, ( Jakarta: Gema Insani Press, 1996) h, 130.

35 Chotibul Umam, Upaya Mengembalikan Manusia Modern Kepada Fitrah Kemanusiaan, Mimbar Ulama No. 176, Tahun 1992, h. 23

${ }^{36}$ Ali Yafie, Dampak Globalisasi dan Peran Ulama, Mimbar Ulama No. 209, Tahun 1996, h. 34 
dalam berbagai aspek kehidupannya. Sebagaimana yang diutarakan oleh A.M. Saefuddin bahwa: abad ke XXI, yakni abad globalisasi yang di tandai oleh kebebasan dan keterbukaan, akan segera di masuki. Abad ini adalah yang penuh harapan, karena ada peluang-peluang positif yang dapat di manfaatkan. Tetapi abad ini juga erupakan abad yang menkutkan karena ada tantangan-tantangan yang negatif yang dapat merusak peradaban manusia dalam banyak sektor kehidupan di planet bumi ini. ${ }^{37}$

Dengan menyimak pandangan yang dikemukakan di atas, dapat dipahami bahwa era globalisasi sebagai suatu era yang di tandai dengan berbagai tantangan di mana tantangan-tantangan tersebut dapat bermanfaat dan membina keberuntungan jika dipahami karakteristiknya. Namundapat pula menjadi suatu ancaman yang membahayakan jika keliru meresponnya. Dalam sebuah tulisannya dengan judul Paradigma Kesamaan Ilmu Pengetahuan dan Agama Menurut Al-Qur'anul Karim, Ikha Rochdjatun Sastra Hidayat mengajukan dua masalah yang akan timbul dalam era globalisasi sebagai tantangan yang akan dihadapi manusia, yakni:

a. Eksploitasi perekonomian dunia terdahulu besar oleh negara donor terhadap bangsa-bangsa penerima bantuan. Dalam kondisi ini terlihat bahwa bantuan moneter dari negara donor jelas tidak meningkatkan potensi ekonomi dari negara penerima bantuan.

b. Masuknya teknologi dan juga tingkat sistem produksi terhadap konsumsi negara. Masuknya teknologi elektronik dalam bentuk TV,

\footnotetext{
${ }^{37}$ A. M. Saefuddin, op. Cit., h. 67
} 
video, film, radio dan lain-lain telah terbukti bahwa paling baik adalah memasuki budaya dimana teknologi itu dihasilkan. ${ }^{38}$

Konsekuensi- konsekuensi dari era globalisasi sebagaimana dipaparkan diatas, juga tidak terlepas dari rapuhnya budaya dan nilai-nilai agama yang ada pada masyarakat sehingga semakin mempercepat berkembangnya pola-pola gaya hidup yang cenderung mengarah kepada disintegrasi dan destruktif. Hal ini merupakan suatu tantangan bagi dunnia pendidikan dewasa ini dan dimasa-masa yang akan datang dimana guru memegang fungsi dan peranan yang urgen.

Tantangan-tantangan yang akan muncul di era globalisasi yang kecenderungannya mulai dirasakan saat ini digambarkan pula oleh Fuad Amsyari yang menyatakan bahwa:....., kesenjangan antara negara maju dan negara yang sedang berkembang dalam status ekonomi semakin melebar tidak mendekat. Persaingan ekonomi biasanya dimenangkan oleh yang kuat, yaitu negara maju. Sumber daya alam dinegara yang sedang berkembang semakin tipis karena di eksploitasi oleh yang kuat. Globalisasi menjadi suatu tema untuk mengkondisikan dunia untuk menyediakan sumber daya alam untuk semakin dieksploitasi lebih luas lagi oleh manusia atas nama pembangunan ekonomi. ${ }^{39}$

Kehidupan pada millennium ketiga benar-benar berada pada tingkat persaingan global yang sangat ketat. Artinya siapa saja yang tidak memenuhi syarat kualitas global, akan tersingkir secara alami dengan sendirinya. Pertanyaannya sudahkah kita siap akan hal itu? Kelihatannya belum. Itulah sebabnya kita perlu selalu melakukan pembaruan dalam

38 Ika Rochjatun Sastra Hidayat, Paradikma Kesamaan Ilmu Pengetahuan dan Agama Menurut Al-Qur'an al-Kariem, Cet I,(Jakarta: Gema Insani Press, 1996), h. 63

39 Fuad Amsyari, Pentingnya Lingkungan Hidup Dalam Kehidupan Manusia Sebagai Ayat-ayat Ilmiah Dalam Al-Qur'an dan As-Sunnah, (Jakarta: GIP 1996) ,h. 199 
bidang pendidikan dari waktu ke waktu tanpa henti. Kita tidak boleh lagi selalu membanggakan keberhasilan masa lalu tanpa mengkaji ulang relevansi keberhasilan itu dengan setting kehidupan global masa kini dan akan datang. Untuk itu kita patut memperhatikan metafora John F. Kennedy yaitu; "Change is a way of life. Those who look to the past or present will miss the future". ${ }^{40}$

Dengan kemajuan yang dicapai dalam bidang ilmu pengetahuan dan teknologi akan semakin memicu perubahan yang terjadi di berbagai bidang kehidupan manusia yang sekaligus berdampak pada pergeseran nilai-nilai budaya dan agama dalam kehidupan umat manusia. Hal inilah yang menjadi tantangan-tantangan yang harus di antisipasi sedini mungkin agar tantangan yang ada tidak menjadi ancaman melainkan menjadi suatu peluang yang menjanjikan.

4. Peluang-peluang di era globalisasi

Disamping lahirnya tantangan-tantangan sebagai konsekuensi dari era globalisasi tersebut, juga membuka peluang-peluang yang perlu dimanfaatkan guna memberi kesejahteraan bagi umat manusia. Peluang-peluang tersebut antara lain:

a. Tersedianya informasi

Dengan tersedianya informasi, berita dari luar negeri yang terdiri dari informasi ilmu pengetahuan dan teknologi (iptek), informasi iman dan takwa (imtak) dan informasi yang merupakan indikator-indikator ekonomi akan mempercepat peningkatan penguasaan ilmu pengetahuan dan teknologi, iman dan takwa serta antisipasi yang cepat serta tepat dalam kegiatan-kegiatan ekonomi.

40 Suyanto dan Jihad Hisyam, Refleksi dan Reformasi Pendidikan di Indonesia Memasuki Millenium III, (Jogyakarta: Adi Cita Karya Nusa, 2000) h,2 
Globalisasi menyentu berbagai bidang kehidupan manusia, seperti kegiatan ekonomi, perdagangan dan kebudayaan yang akan melahirkan karakter peradaban dunia yang berbeda dari peradaban dunia sebelum era globalisasi.

Informasi yang berkembang dengan pesatnya merupakan pemicu terhadap percepatan era globalisasi ini sehingga akan semakin penting fungsi dan peranannya. Ramalan tentang era informasi sebagai bagian dari era globalisasi yang sedang berlangsung, menurut Djalaluddin Rakhmat sebagaimana di kutip oleh Chotibul Umam memiliki karakteristik umum, yakni:

a. Berbeda dengan masyarakat agrikultural yang mengukur kekayaan dengan pemilikan sumber daya alam, dan berbeda dengan masyarakat industrial yang meletakkan kekayaan pada pemilikan alat produksi, masyarakat informasi menjadikan informasi sebagai kekayaan utama. Yang paling penting dalam menetukan dalam masyarakat adalah orang-orang yang paling banyak memiliki informasi

b. Bila masyarakat agrikultural bertumpu pada teknologi kecil, dan masyarakat industrial menggunakan teknologi besar, masyarakat informasi menggunakan teknologi elektronika

c. Penggunaan teknologi elektronik telah mengubah lingkungan informasi dari lingkungan lokal (zaman agrikultural) dan nasional (industrial) ke lingkungan global

d. Peranan media elektronik yang demikian besar akan menggeser agen-agen sosial tradisional; orang tua, guru, pendeta, pemerintah dan sebagainya. 
e. Pada era informasi, yang sanggup survive hanyalah mereka yang berorientasi ke depan, yang bijak (yang mampu mengubah pengetahuan menjadi kebijaksanaan. ${ }^{41}$

Dampak kemajuan teknologi informasi itu ada yang positif dan menguntungkan, dan ada yang merugikan. Di antara dampak positif dan merupakan peluang yang dapat dimanfaatkan adalah adanya kesempatan untuk mengakses lewat permukaan bumi dalam waktu beberapa detik saja, baik dalam bentuk gambar, suara ataupun suara bergambar, sehingga berbagai penemuan yang dihasilkan oleh para ahli atau pakar yang terbaik dapat dihimpun dan disebarkan kepada siapa saja dan dimanapun serta kapan saja.

b. Tersedianya atau masuknya modal

Besarnya jumlah modal yang tersedia diluar negeri yang siap memasuki negara yang lebih menarik untuk melakukan investasi. Hal ini akan menjadi peluang yang positif bagi dunia ekonomi khususnya, dan dunia usaha pada umumnya. Karena dengan terjadinya investasi besar-besaran di berbagai sektor usaha akan mendorong pembukaan lapangan kerja dalam jumlah yang besar dan mendorong pula kesempatan kerja, sehingga memberikan kesempatan bagi masyarakat yang pada akhirnya dapat meningkatkan kesejahteraan mereka.

c. Adanya kebijakan pendidikan dan semakin tingginya tingkat pendapatan

Kebijakan dalam bidang pendidikan yang membuka peluang bagi upaya peningkatan kualitas sumber daya manusia yang berpijak pada konsep "link and match" atau terkaitan dan kesepadanan, yakni adanya keterkaitan antara kebutuhan sumber daya manusia dan

${ }^{41}$ Chotibul Umam, op.cit., h.22 
lapangan kerja, sehingga mendorong dan melaksanakan konsep pendidikan untuk menghasilkan lulusan yang sesuai dengan kebutuhan dunia kerja, baik dari segi kuantitas maupun kualitas, di perkirakan pada tahun 2020, dengan negara yang sedang berkembang dalam wilayah asia pasifik memasuki globalisasi ekonomi. Ini berarti batas negara dalam perdagangan investasi menjadi kabur, oleh karena rintangan-rintangan arus barang, jasa dan modal antara negara yang menjadi anggota APEC menjadi menipis atau hilang sama sekali. Kegiatan perdangan berkaitan dengan proses industrialisasi yang membawa perubahan struktur ekonomi dan kesempatan kerja. Struktur tenaga kerja pun terdeferensiasi,baik secara horizontal maupun maupun vertikal. Proses industrialisasi dan perdagangan menjadi mesin pertumbuhan ekonomi, oleh karena proses ini menciptakan nilai tamab, mengolah bahan menjadi bahan setengah jadi dan barang jadi. ${ }^{42}$

Berbagai kebijakan dalam bidang pendidikan yang di tempuholeh pemerintahan orde baru seperti melalui SKB 3 Mentri tahun 1976, pengangkatan guru melaui program UGK (ujian guru agama), serta undang- undang nomor 2 tahun 1989 tentang sistem pendidikan nasional ternyata masih menggambarkan sikap yang setengah hati dan belum sungguh- sungguh untuk memberdayakan rakyat indonesia melalui dunia pendidikan. Hasil komisi penelitian tim Reformasi pendidikan yang di ketuai Prof. Dr. Soeyanto dari universitas negeri yogyakarta misalnya menyebutkan bahwa pendidikan yang di laksanakan pada zaman orde baru belum mampu menghasilkan pendidikan yang unggul dan memberdayakan peserta didik. Pemerintah orde baru juga belum dapat memeberikan pendidikan yang

\footnotetext{
${ }^{42}$ Badan Pembinaan Pendidikan Pelaksanaan Penghayatan dan Pengamalan Pancasila, op. Cit., h.9
} 
merata bagi seluruh rakyat indonesia, serta belum mampu menghasilkan lulusan yang memiliki wawasan pengetahuan yang luas, keterampilan serta akhlak yang mulia. Berdasarkan kenyataan ini, Tim Reformasi pendidikan ini mengusulkan agar undang- undang no 2 tahun 1989 tentang sistem pendidikan nasional itu segera di perbaharui dengan sistem pendidikan nasional yang memenuhi harapan dan tuntutan era global yang kompetitif. ${ }^{43}$

Kini harapan untuk memperoleh pendidikan yang unggul dan memberdayakan serta merata bagi seluruh rakyat indonesia mulai terbuka. Harapan ini tercermin dalam sejumlah kebijakan strategis yang di tempuh oleh pemerintah kabinet indonesia bersatu dengan lahirnya undang-undang No. 20 tahun 2003 tentang sistem pendidikan nasional, naiknya anggaran pendiikan yang mencapai 20\% dari APBN, undang- undang No 14 tahun 2005 tentang standar nasional pendidikan, peraturan menteri pendidikan nasional RI No.2 tahun 2005 tentang subsidi silang biaya operasional perguruan tinggi, serta peraturan menteri pendidikan nasional No 8 tahun 2005 tentang tata kerja direktorak jenderal penigkatan mutu pendidik dan tenaga kependidikan departemen pendidikan nasional.

Di dalam berbagai undang-undang dan peraturan tersebut terlihat dengan jelas adanya kemauan politik yang kuat dari pemerintah indonesia untuk memberdayakan rakyat indonesia memalui pemberian pendidikan yang unggul dan memberdayakan dengan meninjau kembali seluruh komponen yang terkait dengan pendidikan. Pemerintah dengan jelas telah meletakan standar isi, proses

\footnotetext{
${ }^{43}$ Abuddin Nata, Modernisasi Pendidikan Islam di Indonesia, (Jakarta: UIN Jakarta Press, 2001) h. 7-8
} 
kompetensi lulusan, pendidik dan tenaga kependidikan, sarana dan prasarana, pengelolaan, pembiayaan, dan penilaian pendidikan. ${ }^{44}$

Dalam undang-undang nomor 20 tahun 2003 tentang sistem pendidikan nasioal, pendidikan agama memperoleh perhatian yang sangat besar. Hal ini dapat dilihat dari:

1. Pada bagian pertimbngan RUU sisdiknas butir a dikatakan bahwa UUD 1945 mengamanatkan pada pemerintah agar mengusahakan dan menyelenggarakan suatu sistem pendidikan nasional yang meningkatkan keimanan dan ketakwaan kepada tuhan yang maha esa, serta akhlak yang mulia dalam rangka mencerdaskan kehidupan bangsa yang diatur dengan UU Dasar pertimbangan ini jelas mengisyaratkan tentang pentingnya pendidikan agama, karena masalah keimanan, ketakwaan dan akhlak mulia merupakan misi utama ajaran agama.

2. Bab II pasal 4 UU sisdiknas tersebut dinyatakan bahwa pendidikan nasional bertujuan mengembangkan potensi peserta didik agar menjadi manusia yang beriman dan bertakwa pada tuhan yang maha esa, berakhlak mulia, sehat, berilmu, cakap, kreatif, mandiri, serta menjadi warga negara yang demokratis dan bertanggung jawab dalam rangka mencerdaskan kehidupan bangsa. Untuk menghasilkan orang yang beriman, bertakwa dan berakhlak mulia bagaimana dimaksud tujuan pendidikan tersebut, jelas harus melalui pendidikan agama.

3. Bab V pasal 13 ayat 1 butir a UU sikdiknas dinyatakan bahwa setiap peserta didik pada setiap satuan pendidikan berhak mendapatkan pendidikan agama sesuai dengan agama yang

${ }^{44}$ Ibid, h. 8 
dianutnya dan di ajarkan oleh pendidik yang seagama. Ketentuan ini selain menegaskan adanya hak bagi setiap peserta didik untuk memperoleh pendidikan agama juga agar agama yang di ajarkan pada peserta didik tersebut di berikan oleh guru yang seagama dengannya.

4. Bab X pasal 37 ayat 3 UU sisdiknas disebutkan bahwa kurikulum disusun sesuai dengan memperhatikan: a. Peningkatan iman dan takwa, b. Peningkatan akhlak mulia. Kemudian pada pasal 38 di nyatakan pula bahwa kurikulum pendidikan dasar dan menengah antara lain wajib memuat pendidikan agama. Selanjutnya pada pasal 39 di kemukakan bahwa kurikulum pendidikan tinggi wajib memuat pendidikan agama. $^{45}$

Pasa-pasal pada undang-undang sisdiknas di atas selain memperlihatkan dengan jelas tentang pentingnya pendidikan agama juga menginginkan agar pendidikan agama yang diberikan pada setiap jenjang pendidikan bukan pengajaran agama melainkan benar-benar pendidikan agama. Pendidikan agama yang diharapkan oleh UU sisdiknas tersebut adalah pendidikan agama yang mampu merubah sikap, pola pikir dan pola tinadakan setiap orang yang mempelajari agama. Agama yang dianutnya senantiasa dilibatka dalam setiap pengambilan kebijakan dan keputusan yang di hadapinya.

Untuk menghasilkan sumber daya manusia atau tenaga kerja yang sesuai dengan kebutuhan, maka fungsi dan peranan pendidikan semakin menentukan. Hal ini berkaitan dengan peningkatan dan

${ }^{45}$ Ibid, h.58-60 
kebutuhan sumber daya manusia, baik dari aspek kuantitas maupun kualitas sesuai dengan tuntutan zaman pada era globalisasi.

Dengan semakin tingginya pendidikan masyarakat, maka akan mempermudah penerimaan penyuluhan-penyuluhan dan bimbingan dalam upaya menangkal ideologi yang bertentangan dengan budaya dan nilai-nilai asing

\section{Kesimpulan}

Berdasarkan uraian yang telah dikemukakan di atas maka yang menjadi kesimpulan dalam tulisan ini adalah keberadaan guru bukan hanya sebagai pengajar yang berusaha mentransformasikan (memindahkan) ilmu pengetahuan kepada anak didiknya melainkan juga berperan dalam upaya membina dan membimbing anak didiknya ke arah kemajuan suatu masyarakat bahkan kemajuan suatu bangsa. Dalam menjalankan perannya itu seorang guru tidak dapat terlepas dari tantangan- tantangan yang harus di hadapi dan peluang-peluang yang bisa di dapatkan. Era globalisasi sebagai suatu era yang di tandai dengan berbagai tantangan dimana tantangan-tantangan tersebut dapat bermanfaat dan membina keberuntungan jika di pahami karakteristiknya. Namun dapat pula menjadi suatu ancaman yang membahayakan jika keliru dalam meresponnya. Di samping tantangan yang di hadapi, terdapat pula peluang-peluang yang bisa didapatkan diantaranya adalah tersedianya informasi, modal kebijakan pendidikan dan semakin tingginya pendapatan. 


\section{Daftar Pustaka}

Ahmadi, Abu et all., Psikologi Belajar, (Jakarta: Rineka Cipta, 1991)

Ahmad, Muhammad, Tanggung Jawab Pendidikan Agama Islam (Diktat Ilmu Pendidikan Islam), Ujung Pandang: IAIN Alauddin,1991)

Ali, M.Natsir, Dasar-dasar Ilmu Mendiidik,(Jakarta: Mutiara,1997)

Amsyari,Fuad Pentingnya Lingkungan Hidup Dalam Kehidupan Manusia Sebagai Ayat-ayat Ilmiah Dalam Al-Qur'an dan As-Sunnah, (Jakarta: GIP 1996)

Daradjat, Zakiyah et.all., Ilmu Pendidikan Islam, Jakarta: Bumi Aksara,1992

Departemen Agama RI., Al-Qur'an dan Terjemahnya, (Jakarta: Yayasan Penyelenggara Penterjemah dan Penafsir Al-Qur'an, 1991)

Dewantara,Ki Hajar, Bagian Pertama Pendidikan, (Yogyakarta: Majlis Luhur Persatuan Taman Siswa, 1962),

Ditbimpaisum, Pedoman Pembinaan Guru Agama Islam Pada Sekolah Umum, Jakarta: Dirjen Binbaga Islam Direktorat Pembinaan Pendidikan Agama Islam, $1990 / 1991$

Fadjar A. Malik. Reorientasi pendidikan Islam, (Jakarta Fajar Dunia),1999),

Feisal, Jusuf Amier, Reorientasi Pendidikan Islam, Cet I, ( Jakarta: Gema Insani Press, 1996)

Hidayat, Ika Rochjatun Sastra, Paradikma Kesamaan Ilmu Pengetahuan dan Agama Menurut Al-Qur'an al-Kariem, Cet I,(Jakarta: Gema Insani Press, 1996)

Hidayat, Komaruddin, Memetakan Kembali Struktur Keilmuan Islam Kata Pengantar dalam Fuaduddin dan Cik Hasan Bisri, Dinamika Pemikiran Islam di Perguruan Tinggi: Wacana tentang Pendidikan Agama Islam, (Jakarta: Logos 2002) 
Langgulung, Hasan, Asas-asas Pendidikan Islam, Cet.2, Jakarta: Pustaka AlHusna, 1988 . Manusia dan Pendidikan (Suatu Analisa Psikologis dan Pendidikan) Cet I, Jakarta: Pustaka Al-Husna, 1989

Mappanganro, Implementasi Pendidikan Islam di Sekolah, Cet.1, Ujung Pandang, Ahkam,1996

Marimba, Ahmad D., Pengantar Filsafat Pendidikan Islam, (Bandung: PT.al-Ma'arif , 1981)

Nata, Abuddin, Peranan Pendidkan Agama Dalam Menghadapi Tantangan Abad ke21, (Harian pelita, jumat 7 november 1997)

_. Modernisasi Pendidikan Islam di Indonesia, (Jakarta: UIN Jakarta Press, 2001)

- Peranan Pendidkan Agama Dalam Menghadapi Tantangan Abad ke-21, (Harian pelita, jumat 7 november 1997)

Al-Nahlawi, Abdurrahman, Usul Al-Tarbiyah al-Islamiah wa Aslibuha, (Kairo: Darul Fikri, 1955)

Saefuddin, A. M., Desekularisasi Pemikiran; Landasan Islamisasi, Cet. (Bandung: Mizan, 1997)

_. Pendidikan Pesantren dan Globalisasi Serial Khotbah Jumat. No 203 Mei 1998

Suyanto dan Jihad Hisyam, Refleksi dan Reformasi Pendidikan di Indonesia Memasuki Millenium III, (Jogyakarta: Adi Cita Karya Nusa, 2000) 
Umam, Chotibul, Upaya Mengembalikan Manusia Modern Kepada Fitrah Kemanusiaan, Mimbar Ulama No. 176, Tahun 1992, 